International Journal of Instruction e-ISSN: 1308-1470 • www.e-iji.net
October $2020 \bullet$ Vol.13, No.4

p-ISSN: 1694-609X

pp. 17-34

Received: 27/08/2019

Revision: 17/03/2020

Accepted: 05/04/2020

OnlineFirst:02/07/2020

\title{
National Public Control System in Higher Education: The Bologna Process
}

\section{Elena Ryabova}

National Research Ogarev Mordovia State University (Federal State Budgetary Academic Institution of Higher Education), Russia, rabovaelena978@gmail.com

Tatyana Cherkasova

National Research Ogarev Mordovia State University (Federal State Budgetary Academic Institution of Higher Education), Russia, tat.vl.76@bk.ru

This study aims to assess the work of supervisory and control authorities in the field of education, as well as to create public control mechanisms for monitoring their activities and the quality of higher education. The research is based on the sociological data obtained by interviewing the members of civil society and the representatives of the education system. The methodological basis of the research is a systematic, comprehensive, structural-functional, institutional approach to the consideration of the public control in the education system. A permanent network of expert organizations should form for education quality. Control and supervisory authorities in the field of education should work more closely with the representatives of civil society. This can be performed through the organization of public councils within the control and supervisory authorities, and in higher educational institutions. The changes in the organization and implementation of public control in higher educational institutions are needed, namely: development of clear and objective procedures for assessing the quality of public university educational services; eliminating unnecessary formalities and bureaucracy in higher education during testing; ensuring greater transparency and accessibility of the results of the state audit to familiarize the public with the reports via the Internet. State regulatory authorities should evaluate not only the educational process, but also the educational activities of higher educational institutions.

Keywords: public control, higher education, educational institutions, mechanisms, supervisory authorities in education

\section{INTRODUCTION}

Education is an integral part of any society (Internationalisation and Trade in Higher Education, ${ }^{2004)}$. The quality of higher education significantly affects the quality of life and workforce in the country. There is a state and public demand for the effective

Citation: Ryabova, E., \& Cherkasova, T. (2020). National Public Control System in Higher Education: The Bologna Process. International Journal of Instruction, 13(4), 17-34. https://doi.org/10.29333/iji.2020.1342a 
functioning of the education system in many countries, which makes it necessary to introduce public control in this area (Internationalisation and Trade in Higher Education ${ }^{2004}$ ). It should be noted that there are two systems for assessing the quality of education abroad. In the first system, the state plays a dominant role and civil institutions are involved (this system is typical for the countries where there are control authorities in the education system). In the second system, education quality control is ensured through self-assessment by educational organizations of their activities (this system is typical for the countries where the process of self-education prevails).

At the same time, the system for assessing the quality of education in a number of Western countries is constantly being improved and changed, combining various techniques, mechanisms, and subjects. In particular, in the universities of the United Kingdom and the Netherlands, a three-level system of assessment and control of the quality of educational services is used: state control; independent audit of universities by public expert councils; self-assessment of educational activities conducted by universities themselves (Werkleigh et al., 2019).

It should be noted that public control of the quality of education in foreign countries is carried out by independent expert communities or by the parent community, whose children are consumers of educational services (Anderson \& Minke, 2010; Crea et al., 2015). As a result, there are contradictory requirements for foreign educational organizations and the lack of uniform standards for assessing universities. In addition, foreign research devoted to public control is limited to the study and discussion of the assessing criteria of education quality. Most authors (Kohl et al., 2000; Heyneman, 2004; Hakhverdian \& Mayne, 2012) highlight the priority and importance of such indicators as accessibility of education for the country's population, the absence of discrimination in getting education for various population groups, honesty and openness of an educational organization, accountability and publicity of its functioning. At the same time, citizens and, above all, parents increasingly criticize these criteria and their application in public control. In Western countries, parents remark on the limitations of public control objects and criteria, wishing to get the assessment results and the very educational content that is presented to the students (Stensaker \& Harvey, 2006; Veronese et al., 2015).

Public quality control of education in Western countries is also characterized by the assessment of students' and graduates' knowledge through testing. At the same time, testing in foreign educational institutions is increasingly changing from ordinary tests in the form of closed-ended questions to a system of various standardized tasks. In addition to the assessment of students' knowledge, funding of foreign educational organizations is one of the important objects of public control. The education management authority or a private auditor is not engaged in the education system. The public control over education financing conducted in foreign countries makes it possible to assess the performance of an educational organization, as well as to reveal and prevent corruption in the education system. However, despite a huge number of studies and implemented practices against corruption, this problem remains relevant and unresolved in the higher education system of many foreign countries. 
The ongoing global socioeconomic changes in the education system change the tasks and purposes of public control in many countries. There is a gradual transition from the perception of public control as a means of identifying shortcomings and a punitive agency to its understanding as a mechanism for cooperation between the state and public structures to improve the quality of education in the country. Knowledge and proper application of these features and mechanisms of public control of education in foreign countries is also extremely important for the Russian education system. In modern Russia, researchers are increasingly interested in the role and importance of public control in the education sector due to the following factors:

1) Reforming the system of financing educational institutions, including the transition to the relative financial independence, as well as the introduction of a new remuneration scheme, remuneration depending on the results of scientific and educational activities.

2) Improved education management system based on the idea of expanding public control; requirements to increase openness, transparency and objectivity of the educational and management process, including the introduction of public reporting on the status and effectiveness of all educational organizations.

3) Awareness of the fact that a simple legislative regulation or government institutions are not able to solve the key issues in education.

Thus, the aim of this study is to analyze the national public control system in higher Education, as well as to create public control mechanisms for monitoring their activities and the quality of higher education, which is highly demanded in Russia. Since in the Russian education system the state is the subject forming the main requirements for assessing the quality of educational services, the authors of this research paid special attention to the activities of public authorities in the education sector.

\section{LITERATURE REVIEW}

Public control is a democratic institution that allows society to control the activities of the government. The overwhelming majority of modern researchers: Butenko (2012), Yagudina (2013), Shestakova (2008), Nevinskii (2009), Barabanova (2007; 2013) agree upon the following. Public control is the activity of civil society and individual citizens. Public authority's compliance with the legislation is the aim of public control. Along with the correction of identified deviations. Moreover, the correction function can be performed by contacting public authorities, or through the public decision.

Two approaches to the study of the "public control" concept can be distinguished. Semantic approach deals with the essential characteristics of the phenomenon and the main task of the researcher is to cover them. This is public control of the government activity in a particular historical period. Functional approach defines public control as the activity of non-governmental institutions and individual citizens (Zubarev, 2011). Modern integration processes in Europe have necessitated the modernization of national education systems. The changes affected the content of education, the tools and methods of training, management mechanisms, education and professional training quality assessment (Zeer, Tretyakova \& Miroshnichenko, 2019). 
The European Union has taken a number of measures aimed at creating a system for comparing qualifications. In higher education, this activity is known as the "Bologna Process"; its main task is to create a competitive economy based on a high-level preparation of specialists within the EU. Adaptation of Russian education to the requirements of international educational standards is a priority of modern state policy. The search for new forms and methods of managing the educational environment, combining the traditions of Soviet education with advanced educational technologies of foreign countries is one of the main state objectives.

In foreign countries, public control is often referred to as a procedure that has become known for a certain "standard of relations between universities, society and the state, the balance of their rights and obligations, certain autonomy and their responsibilities" (Trainev et al., 2008).

In the framework of the Bologna process, the students' opinion is a necessary and important tool for assessing the quality of education (Standards and Guidelines for Quality Assurance in the European Higher Education Area, 2015). The method or toolkit for identifying the opinions of educational services consumers is one of the aspects of public control in higher education, which should be studied separately. The results of surveys of public satisfaction with the quality of education should be included in public reporting, reflecting the degree of compliance of the current level of education with the demands of consumers (Demtriou, 2008). Other authors point out that when preparing and analyzing statistics on the quality of education, the conclusions and recommendations should be based on the "Satisfaction Index" (Zhang et al., 2008), or the "Customer Satisfaction Index" (CSI), which is used to compare research results, regardless of the research method. At the same time, the model for calculating this indicator remains the subject of many scientific discussions (Huili \& Jing, 2012). In particular, the methodological substantiation of the CSI calculation occurs within the framework of the model measurement methodology. From the practical point of view, the most reliable methods are the techniques that have economic approbation in various services, including commercial services (Luo et al., 2013), and guarantee the possibility of comparing data (by type of service) in a single quantitative model.

According to the Federal Law No. 273-FZ of December 29, 2012 "On Education in the Russian Federation", one of the principles of state education policy is a combination of public and contractual regulation of relations in education (The Federal Law, 2012). Public participation in the management and assessment of educational institutions and governments is important for the education system. Public participation is needed for a proper assessment procedure and harmonizing the state and public order on the quality of educational services. There is the Federal Law No. 212-FZ of July 21, 2014 "On the basis of public control in the Russian Federation". According to the mentioned Law, public control is the activity of the public control bodies, carried out in order to monitor the activities of public authorities, local governments, state and municipal organizations, other bodies and organizations performing certain public functions. Other purposes of the public control bodies include public inspection, analysis, and evaluation of the issued public acts and taken decisions (The Federal Law, 2014). 
In this regard, the development of public control mechanisms in higher education is of particular interest. The main objectives of the public control of higher educational institutions are the following:

- Strengthening the role of civil society.

- Improving the efficiency of cooperation between the state and public higher educational institutions.

- Improving the learning environment in higher education.

- Ensuring effective public control of the government policy implementation in higher education.

The American accreditation system is the most popular and the most widely used system in the world, including in Russia. It has more than a century of history and is of a statepublic nature. The most important condition of the traditional American model is an external examination by public associations (Tretiakova, 2009). The control structure in the United States has two forms: the assessment of the educational institution as a whole, and the assessment of educational programs. The quality assessment is based on expert opinion (Campbell \& Rossnyai, 2002), and on the public ranking system data. The process of accreditation in the United States performs a dual function: determining the compliance of learning outcomes with standards, and obtaining information to improve the process and learning outcomes (Zvonnikov \& Chelyshkova, 2007).

In the Netherlands, the quality of education is monitored with the aim of improving the process of training and teaching. Educational institutions are accountable to the state and the public for spending money. Educational institutions observe the Bologna agreements, and inform the public about the quality of educational programs. The control is carried out in two directions: self-examination and external examination. The decision on each educational program is made by the "Commission of Equals", which includes representatives of both groups. When the work of all experts and the main expert group is completed, a written report is prepared. It is published in the press and on the Internet in order to encourage the educational organization to improve the educational process, inform the public (Ministry of Education, employers, students, parents, etc.) about the real quality of education (Akkreditierungsrat, 2002).

The education system in Germany is characterized by an assessment of the most general indicators of the functioning of educational institutions without a detailed study of educational processes and the assessment of professional programs, as well as by the restriction of thorough state control (Tretiakova, 2009). The creation of test examination papers and verification of results is carried out centrally only in six German regions. Three out of the six accreditation agencies are narrowly specialized: they were established for the accreditation of technical, medical and business programs. The other three agencies are widely specialized in the accreditation of various areas and institutions in general (Akkreditierungsrat, 2002). Accreditation agencies work on their own criteria and do not depend on each other. 
Today, the potential of public control in Russia has not been fully disclosed. The development and testing of new forms of cooperation between state and public institutions in the field of control and supervision in education will lead to the following:

- Exploring and analyzing the advanced domestic and foreign experiences.

- Disseminating and implementing the best models of work with civil society organizations, including public anti-corruption association.

- Improving legal and regulatory framework of public control in education.

Thus, the purpose of the research is to study the work of supervisory and control authorities in the field of education, as well as to create public control mechanisms for monitoring their activities and the quality of higher education.

\section{METHOD}

\section{Research Design}

The methodological basis of the research is a systematic, comprehensive, structuralfunctional, institutional approach to the consideration of the public control in the education system.

\section{Study Sample}

The sociological survey involved 640 people directly involved in the educational services provided by higher educational institutions. The percentage of male and female respondents was not equal: men $-39.1 \%$ and women $-60.1 \%$. In terms of education, the respondents were divided into the following groups: $0.6 \%$ completed secondary school; $0.6 \%$ received secondary special education; $0.6 \%$ - incomplete higher education; $98.2 \%$ - higher education. A significant proportion of the respondents who received higher education had a degree or an academic title. Respondents did not differ in terms of social composition, as they all were the employees of higher educational institutions. Fifty point two per cent of the respondents indicated themselves as professionals, $47.4 \%$ - employees, $1.2 \%$ - pensioners, $0.6 \%$ - students, $0.6 \%$ - workers. A survey of the working respondents revealed that they were mainly involved in pedagogy, science and education $-86.3 \%$. A minor proportion of the respondents was involved in the following areas: $8.5 \%$ - administrative structures, $3.9 \%$ - engineering and technical sphere, $1.3 \%$ economy and business.

Eighteen per cent of respondents participated in the public control procedures as objects of inspection, and $22 \%$ - as invited experts. It should be noted that some respondents were both invited experts and public control objects of inspection and assessment. Many respondents have never participated in public control - 64\%.

\section{Survey}

A questionnaire was developed in accordance with the purpose and objectives of the research. It includes 22 questions aimed at identifying various aspects of the implementation of public control in higher education, as well as public control 
mechanisms for monitoring their activities and the quality of higher education. The questions are about the following matters:

- Understanding the necessity of introducing public control in the field of education.

- Public control as a tool for assessing the quality of higher education.

- The assessment of the activities of state control and supervisory authorities in the education system.

The survey involved intramural, extramural and distance learning students.

\section{Data Analysis}

The data obtained from the survey questionnaires were digitized. A database was created, which included the responses of the 640 respondents to the questionnaire questions. The analysis of results of this quantitative research was conducted using the statistical software Excel.

\section{Research Limitations}

The respondents used a 10-point scale to evaluate the activities of the control and supervisory authorities in the field of education. They had to assess the interaction of the authorities with civil society when carrying out public control over higher education (1 very bad organization and interaction, 10 - very good). The average score was 4.5. According to the respondents, the interaction is not good. Consequently, the activities of control and supervisory authorities in the field of education should be reformed. For most respondents the principle of transparency and openness of the activities of control and supervisory authorities in the field of education, particularly in higher education, is quite important.

\section{FINDINGS}

\section{Prospects for the Introduction of Public Control over Higher Education}

Public control in the field of education, particularly in higher education, is still at the beginning. All the respondents (100\%) reported that public control in the field of education must be actively developed and implemented in practice. However, despite the importance of the public control introduction in the sphere of education, which has been noted, the need for its introduction at the level of higher education, is fully support part of the respondents and part of the respondents partially affirmative. The answers on the need to introduce public control at the level of higher education was distributed as follows: $34 \%$ answered "yes", $43 \%$ chose the answer "more likely yes than no", 13\% "more likely no than yes", $10 \%$ answered "no."

This trend may be explained by the fact that higher education is currently being modernized and reformed and the introduction of public control, as any innovation, raises some concerns and doubts.

The main structural effects of introducing public control in the higher education system might be as follows: 
- Encouraging all educational process participants to take actions to improve the quality of education (27\%).

- Increasing public awareness of educational organization and institution activities (24\%).

- Increasing the responsibility of citizens for the results of education (12\%).

- Increasing the motivation of society to improve the activity of educational institutions (12\%).

- Public participation in decision-making on key issues in the development of the education system (9\%).

The respondents ranked (from 3 to 5) the importance of public control functions in higher education as follows:

- The function of carrying out an independent examination of the quality of public educational projects is considered the most important ( 3.9 points).

- Ensuring the compliance with Russian legislation in the field of education, particularly higher education (3.8 points).

- Improving the quality of educational process at university (3.6 points).

Having identified the priority (on a 5-point scale) of public control objects in higher education, the respondents singled out the websites of educational institutions (2.7 points) and the activities of the authorities and institutions carrying out public control (supervision) in the field of education (2.43 points).

This distribution of public control objects may be connected with the respondents' perception of the external audit work of the educational organization - websites with publicly available information, i.e. public control should be carried out on the information that is already available to the public. The respondents believe that the internal conditions of the educational process should not be so often subjected to social assessment and verification. Many respondents pointed to the general need to reduce and shorten government inspections in higher educational institutions.

The respondents were asked to identify the most effective forms of public control at the level of higher education.

According to the respondents, the effectiveness of public control in higher education as a tool to combat corruption is highly controversial. According to the data obtained in the study, only $3 \%$ of the respondents believe that an effective public control mechanism will eliminate corruption in higher education, and the same number of the respondents considers this mechanism ineffective; $60 \%$ of the respondents chose the answer "rather effective" and 34\% - "rather ineffective". This fact shows that on the one hand, public control can and should be a tool and mechanism to combat corruption in higher education, but on the other hand, there are certain contradictions between its need and the real possibilities of its implementation in higher education. 
Figure 1 shows the selected public control forms.

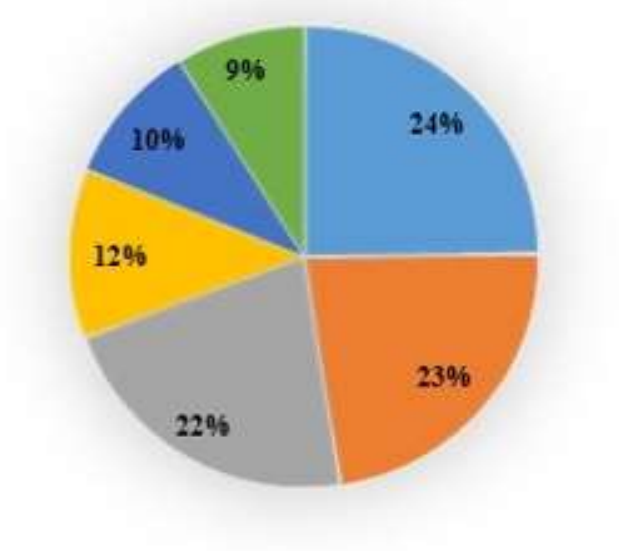

\author{
Public discussion \\ Public inspection \\ Public monitoring \\ Public listening \\ Public investigation \\ Public check
}

Figure 1

The Importance of Public Control forms in Higher Education, \%

The following answers of respondents have been received: $24 \%$ of respondents believe that public discussion is important, $23 \%$ - public inspection, $22 \%$ - public monitoring. Less important is public check $-9 \%$.

The distribution of the respondents' opinions on the public control forms in the field of combating corruption in higher education is quite interesting. The importance of public control forms in combating corruption in higher education is as follows:

- Public check of the decisions made, including the distribution, expenditure and control of budgetary funds of secondary educational institutions $-88.8 \%$.

- Operation of "hotlines" to solve the issues of secondary education $-75.6 \%$.

- $\quad$ Establishment of public councils at all levels of educational institutions - $63 \%$.

- State support for self-organization of citizens in order to protect their constitutional rights in the field of secondary education $-61.74 \%$.

- Establishment of a special procedure for the consideration of citizens' appeals about the facts of corruption in education $-57.9 \%$.

- Ensuring access to information on the activities of secondary education institutions $-56.07 \%$.

- Informing the public about the implementation of anti-corruption programs in secondary education $-31.5 \%$.

Such ratio of the responses to the questionnaire can be explained by the fact that public control has recently acquired the status of a separate institution in Russia. It is being 
actively implemented in all spheres of life. However, many people do not have a clear idea of the content, functions and structure of the institution.

\section{Assessment of the activities of control and supervisory authorities in the field of education}

Thus, $34.2 \%$ of the respondents believe that the representatives of civil society should have access to any information related to the activities of control and supervisory authorities in the field of education. Forty-three per cent of the respondents also noted the importance of access to information concerning the adoption of legal acts and documents regulating the work of higher educational institutions. A smaller percentage of the respondents (22.8\%) believe that access to such information should be restricted, and the permission to receive it should be given at the discretion of control and supervisory authorities.

This trend may be explained by a subjective factor, i.e. the fact that different respondents see the content, features and the main purpose of public control based on their knowledge and experience of participation in this process.

Figure 2 shows the responses to the question whether control and supervisory authorities in the field of education should take into account the recommendations on the results of public control in higher education.

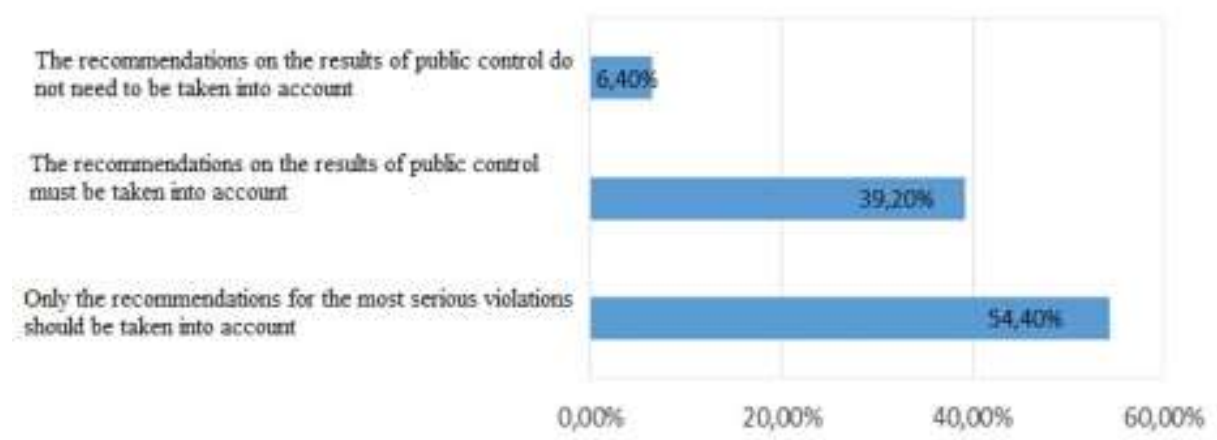

Figure 2

The Need to Consider the Recommendations on the Results of Public Control, \%

Most respondents consider $(54,40 \%)$ only the recommendations for the most serious violations should be taken into account.

The respondents' opinions on the need to improve the system and structure of control and supervision in education, particularly in higher education, were also identified in the study. About $78.2 \%$ of the respondents indicated the need for improvement, suggesting the expansion of the expert community, openness and accessibility of the process of control and supervision of higher educational institutions. The respondents also indicated the need for involvement of the representatives of civil society in monitoring and supervision activities in higher education. 
Some respondents argued that there is no need to improve the system and structure of control and supervisory authorities in the field of education (21.8\%). Their position was justified by the following facts: control and supervisory authorities cope with their functions effectively; possible changes could lead to the expansion of the system and the structure of regulatory authorities.

Nevertheless, it can be noted that the system and the structure of the control and supervisory authorities at the level of higher education should be improved in the Russian Federation.

Currently, there is a number of pressing issues for the introduction of public control at the level of higher education. These are as follows:

- The lack of interest of the educational process participants in changing the educational management system;

- Insufficient power of public bodies to influence the government in the policymaking process in educational area;

- The lack of practical public control of the quality of educational services and the lack of transparency of the information about the activities of educational institutions and regulatory authorities in the field of education.

\section{DISCUSSION}

The study shows that public control in the Russian system of higher education is perceived as the activity of public organizations and the initiatives of citizens to assess accessibility and conditions for obtaining education. This reflects Russia's tendency in the development of education: there is an orientation towards meeting the interests of educational services consumers (students and their parents). This, in turn, determines another feature of Russian universities: if the needs of students and parents are met, the attractiveness of the university increases and there is a constant influx of applicants. Undoubtedly, assessment of educational services by consumers is an important task of public control. However, this is not the only challenge, since the main consumers of graduates' knowledge and skills are their future employers. Nevertheless, at the moment, insufficient attention is paid to attracting representatives of Russian business and employers to the public control procedure in the higher education system. In this case, a vivid example of a number of Western countries can be given. In these countries, the assessment of the performance of an educational organization is carried out through the demand for its graduates in the labor market. The prestige of the university depends on the labor market prices and the actual employment rate of its graduates. In the conditions of higher education rapid development in the United States, Americans also take care of other consumers of educational services - employers. This is confirmed by the fact that accreditation of universities is carried out according to educational standards. The standardization of higher professional education is considered an element of the quality management system of higher education (Rubin, 2004). 
In addition, the need to introduce public control of the quality of education in Western universities is explained not only by the desire to meet the needs of citizens and employers, but also by a number of other factors:

- The society needs the requirements for higher education systems, including the content, volume, forms and methods of knowledge transfer (Vlasceanu et al., 2002).

- State liberalization of the education administration (Palomar \& Parellada, 2002).

- Changes in the "quality of education" concept, which also includes assessments of rationality and cost effectiveness of education (Jackson \& Lund, 2002).

- The need for purposeful activities to create quality control systems for higher education (Watson, ${ }^{2003)}$.

- Many Western countries give autonomy to public administration of the higher education system, which is associated with the global trends.

These trends are not yet fully marked in Russia, but given their global nature, the Russian education system should be prepared for their influence and, accordingly, the active introduction of public control in universities.

Further analysis of the legislative acts and survey results showed uncertainty and the lack of a detailed description of those objects and people that will be included in public control committees and groups in higher education in Russia. There are still no clear criteria for the selection of experts to assess the quality of higher education. Undoubtedly, one of the important criteria should be the awareness and knowledge of the features of higher education system functioning, and expertise in the relevant educational area, which is a public control object. The necessity and validity of this criterion for the selection of public control objects is confirmed by the long-standing and successful practice of a number of Western countries to involve professional communities in assessing the quality of higher education. In particular, British approaches to the control and quality assurance of higher education are based on a system of external assessment and the activities of independent experts. Along with the licensing or accreditation conducted by independent professional associations (Kokhanov, 2016).

At the same time, in a number of foreign universities faculty members are increasingly often attracted to control the quality of education, develop teaching standards and conduct the activities, which would primarily reflect real positive achievements of students in the educational process (Duderstadt, 2000).

In general, there is a tendency to establish and develop special intermediary organizations - agencies for monitoring quality and efficiency of all university activities. The transfer of power for quality control to non-governmental organizations in the new system of relations between the government and universities provides a number of advantages. Governments are exempt from direct responsibility for evaluating the activities of universities and their development. Universities have the opportunity to 
appeal to the government if they disagree with the results of the agency. In addition, in many cases, the findings of agencies are advisory and formally do not affect the independence of universities. However, the opinion of agencies is of great importance for the ministries of education when making decisions regarding specific universities. In this regard, Austria is an interesting example. According to the Austrian law, the information about the results of a university's audit by independent experts is confidential: it is communicated only to the university management and is not subject to publicity (Follet, 2000). Thus, the agencies allow the university management system to ensure a balance between effective quality control, preservation of academic freedom of universities and the development of self-government.

In some countries, for example, in Ireland, the criteria for assessing the quality of education is still unregulated: according to the legislation, quality control must be carried out at every university, and the agency is only concerned with monitoring this procedure. In the United Kingdom, a special agency deals with quality control, and its assessment depends, in particular, on the financing of university research activities. A major role in quality assurance is played by university rankings, which are based on very complex assessment systems and, as a rule, are compiled by various non-governmental organizations (Follet, 2000).

By the end of the twentieth century the international infrastructure of organizations to promote the assessment and maintenance of the quality of higher education was developed. It includes a number of organizations and institutions operating at the global or regional level.

The European Network for Quality Assurance in Higher Education (ENQA) is one of these organizations (Vlasceanu et al., 2002). In 1994-1995, the so-called European pilot projects initiated by the European Commission formed the basis for the basic quality assurance methodology: agency independence, self-assessment, university reports available to the public. The European Network for Quality Assurance in Higher Education was established to be the main platform for the exchange of experience in solving the problems of the quality of higher education in Europe (Vlasceanu et al., 2002).

It is an important task to develop a unified international system of information on the quality of educational services. International principles and real mechanisms should also be developed to ensure the quality of educational services within the framework of various forms of cross-border education. These tasks are designed to address the joint principles on quality assurance of cross-border education (UNESCO/OECD Guidelines on Quality Provision in Cross-Border Higher Education) which were developed by the OECD countries with the active participation of national agencies and universities (International Association of Universities). This project should result in the creation of a unified information base of universities that have received the status of internationally recognized educational institutions (Internationally Recognized Higher Education Institution) (Vlasceanu et al., 2002). 
It should be noted that there is another trend in the countries of Western Europe to ensure control in higher education: the transition from quality assessment to the accreditation system. It was first introduced by the Netherlands in 2003, and in 2005 the Nederlands-Vlaamse Accreditatie Organisatie (NVAO) established it. Since 2003, all university programs in the Netherlands are accredited every six years. The process consists of four stages: the preparation of a self-assessment report by the educational institution; an external expert committee's visit for inspection and assessment; an external expert committee's conclusion; decision made by NVAO (De Korte, 2014). There has been shift from improvement to accountability and the responsibility for quality assurance has been removed from higher education institutions (Westerheijden, 2007). However, this accreditation system was revised in the light of the development of the Bologna process, and its new version has been operating in the Netherlands since 2012.

There are different approaches to monitoring the quality of education in Europe: assessment of the educational institution as a whole (France); quality assessment of individual educational programs (countries of Western and Central Europe); assessment of individual academic disciplines or areas of university activity (Finland, Denmark). These approaches to assess the quality of education are also found in Russia. The implementation of public control and supervision over higher education is a function of the state. The research is aimed at identifying the need to introduce the institution of public observers as a mechanism for external independent assessment of the quality of higher education, and a mechanism for public monitoring/supervision of government authorities in the education system. The international experience must be taken into account while introducing public control into the Russian education system. A number of recommendations are suggested for the development and improvement of the public control mechanisms in the field of higher education.

The implementation of public control in higher education should have a proper legal basis (the general federal law). At the same time, the regulatory framework for the public control in higher education should take into account the disputes consideration on the results of inspections in higher education. Along with the most common deficiencies that are identified during audits.

Public control should not be aimed only at identifying shortcomings in the work of higher education authorities and institutions, but also at developing recommendations for the improvement of educational services. The proposals must relate to both the content of educational programs and methods of training.

The efforts of civil society institutions to carry out inspections in higher educational institutions should become more open and the information on such inspections should be more accessible. It is necessary to create a comprehensive system of informing the public about the opportunities to participate in the management of education.

The necessary changes in public control of educational institutions include:

- Development of clear and accurate criteria for assessing the quality of university educational services. 
- Establishment of the optimal frequency of public inspections of the educational institution that does not exceed the frequency of government inspections.

- Elimination of excessive formalism and bias in carrying out public control in higher education.

- Selection of competent experts for public inspection among the people that have suitable education and work experience in the field of higher education.

A key condition for the effective public control of the higher education authorities is to institutionalize public participation in the management of education. Civil society institutions should be engaged in the following:

- Development and implementation of educational policies, strategies and programs for the development of higher education.

- Formation of the resource base and the education budget, as well as monitoring of their effective implementation.

- Formation of social and civil order in the content and quality of higher education, and orientation of the education system to its implementation.

- Implementation of quality control of public education.

\section{CONCLUSIONS}

The following ways to improve the system and structure of control and supervision in the field of higher education can be suggested. The expert community should expand. A permanent network of expert organizations should form. Such expert organizations are actively involved in expertise of the education quality. Hence, they must be provided with informational, methodological and other support. Control and supervisory authorities in the field of education should work more closely with the representatives of civil society. This can be performed through the organization of public councils within the control and supervisory authorities, and in higher educational institutions. The authorities responsible for the control and supervision of education should more strictly monitor the introduction and development of public control in higher educational institutions. The changes in the organization and implementation of public control in higher educational institutions are needed, namely:

- Development of clear and objective procedures for assessing the quality of public university educational services.

- Eliminating unnecessary formalities and bureaucracy in higher education during testing.

- Ensuring greater transparency and accessibility of the results of the state audit to familiarize the public with the reports via the Internet.

State regulatory authorities should evaluate not only the educational process, but also the educational activities of higher educational institutions. The implementation of these 
recommendations will require further research of both Russian and foreign experience of public control in higher education. Thus, in recent years the emphasis has been placed on improving the system and structure of control and supervision in education in general, and particularly at the level of higher education, and on mechanisms for monitoring the activities of control and supervisory authorities in the field of education. At the same time, such mechanisms have not been clearly developed, and the involvement of public observers to the procedures of the public control (supervision) in the field of education is used only for certain types of educational institutions.

\section{REFERENCES}

Akkreditierungsrat (2002). Work report 2000/2001. Bonn: Head Office of the Akkreditierungsrat.

Anderson, K., \& Minke, K. (2010). Parental involvement in education: Toward an understanding of parents' decision making. The Journal of Educational Research, 100(5), 311-323.

Barabanova, S. V. (2007). The issue of public participation in the regional educational policy: through the example of the Tatarstan Republic. The Yearbook of the Russian Education Legislation, 2, 42-53.

Barabanova, S. V., \& Osintsev, D. V. (2013). Methods of administrative and legal effect in education. The Yearbook of the Russian Education Legislation, 8, 25-39.

Butenko, Yu. V. (2012). State accreditation in the system of university quality assessment. Bulletin of Volgograd State University. University Education, 6(3), 55-61.

Campbell, C., \& Rossnyai, C. (2002). Handbook on quality assurance and the design of study programmes. Bucharest: UNESCO/ CEPES.

Crea, T. M., Reynolds, A. D., \& Degnan, E. (2015). Parent engagement at a Cristo Rey High School: Building home-school partnerships in a multicultural immigrant community. Journal of Catholic Education, 19(1), 223-242.

De Korte, E. (2014). Analysis of university activities in Western Europe: From quality assessment to accreditation. Education Issues, 4, 36-57.

Demetriou, C. (2008). Arguments against applying a customer-service paradigm. Academic Advising Journal, 10(3). Retrieved from http://www.psu.edu/dus/mentor/080930cd.htm

Duderstadt, J. (2000). A university for 21 st century. Ann Arbor: University of Michigan.

Follet, B. K. (2000). Financing a research university - the diversified funding base. IMHE General Conference 2000, Paris.

Hakhverdian, A., \& Mayne, Q. (2012). Institutional trust, education, and corruption: A micro-macro interactive approach. Journal of Politics, 74(3), 739-750. 
Heyneman, S. (2004). Education and corruption. International Journal of Educational Development, 24(6), 637-648.

Huili, Y., \& Jing, Y. (2012). Empirical research and model building about customer satisfaction index on postgraduate education service quality. Canadian Social Science, $8(1), 108-113$.

Internationalization and Trade in Higher Education. (2004). Opportunities and challenges. OECD.

Jackson, N., \& Lund, H. (2000). Benchmarking for higher education. National Science Foundation: Science and Engineering Indicators. Retrieved from http://www.nsf.gov/statistics/seindO2/UT.

Kohl, G., Lengua, L., \& McMahon, RJ. (2000). Parent involvement in school: Conceptualizing multiple dimensions of their relations with family and demographic risk factors. Journal of School Psychology, 38(6), 501-523.

Kokhanov, R. I. (2016). Foreign experience of interaction between state and public institutions for quality management of higher education. Young Scientist, 20, 520-528.

Luo, L., Ratchford, B. T., \& Yang, B. (2013). Why we do what we do: A model of activity consumption. Journal of Marketing Research, 50(1), 24-43.

Nevinskii, V. V. (2009). System of criteria indicators in the ranking mechanisms of the Russian universities and education quality improvement. Bulletin of Tyumen State University, 4, 61-66.

Palomar, A. J., \& Parellada, M. (2002). Continuing education in universities: Policies and Instruments. Barcelona: Columbus Manual.

Rubin, Yu. B. (2004). Globalization and the convergence of education: the technological aspect: Scientific publication. M.: LLC Market DS Corporation.

Shestakova, M. V. (2008). Foreign models of education quality assessment. Human Ecology, 11, 23-28.

Standards and Guidelines for Quality Assurance in the European Higher Education Area (ESG). (2015). Brussels, Belgium. Retrieved from https://enqa.eu/wpcontent/uploads/2015/11/ESG_2015.pdf.

Stensaker, B., \& Harvey, L. (2006). Old wine in new bottles? A comparison of public and private accreditation schemes in higher education. Higher Education Policy, 19, 6585 .

The Federal Law (2012). No. 273-FZ of December 29, 2012 "On Education in the Russian Federation." Retrieved from http://ivo.garant.ru/\#/ document/70291362/paragraph/1:7. 
The Federal Law (2014). No. 212-FZ of July 21, 2014 "On the basis of public control in the Russian Federation." Retrieved from http://ivo.garant.ru/\#/document 170700452/paragraph/1:2.

Trainev, V. A. Mkrtchyan, S. S., \& Saveliev, A. Ya. (2008). Improving the quality of higher education and the Bologna process. Generalization of domestic and foreign practice, 392.

Tretiakova, T. V. (2009). Analysis of approaches to the quality assessment of education abroad. Bulletin of YAGU, 6(2), 59-64.

Veronese, G., Pepe, A., Jaradah, A., Murannak, F., \& Hamdouna, H. (2015). Quality of life and determinants of parents' school satisfaction in war contexts: A mixed-method exploratory study in Palestine. Sage Open, 5(4). https://doi.org/10.1177/2158244015608422.

Vlasceanu, L, Grunberg, L., \& Parlea, D. (2002). Quality assurance and accreditation: A glossary of basic terms and definition. Bucharest: UNESCO.

Watson, D. (2003). Changing patterns of governance in higher education. OECD. Managing Universities and Colleges: Guides to good practice Managing strategy.

Werkleigh, A., Westerheiden, D., Zhelyazkova, M., \& Motova, G. (2019). Principles of self-examination. Pilot version. Center for Higher Education Policy Studies (CHEPS), University of Twente (Netherlands), Scientific Information Center for State Accreditation (RF).

Westerheijden, D. F. (2007). The changing concepts of quality in the assessment of study programmes, teaching and learning. Quality Assessment for Higher Education in Europe. London: Portland.

Yagudina, L. R. (2013). Quality assessment of higher education in Italy. Bulletin of Tomsk State Pedagogical University, 9(137), 93-99.

Zeer, E. F., Tretyakova, V. S., \& Miroshnichenko, V. I. (2019). Strategic directions of pedagogical personnel training for the system of continuing vocational education. The Education and Science Journal, 21(6), 93-121. (In Russian) https://doi.org/10.17853/1994-5639-2019-6-93-121.

Zhang, L., Han, Z., \& Gao, Q. (2008). Empirical study on the student satisfaction index in higher education. International Journal of Business and Management, 3(9), 46-51.

Zubarev, S. M. (2011). The concept and essence of public control over the activity of state bodies. Administrative Law and Procedure, 5, 5.

Zvonnikov, V. I., \& Chelyshkova, M. B. (2007). Foreign experience of creating systems for assessing the quality of education: Materials of the interregional meeting. M., 101115 . 